\title{
Prostatic Urethra Cancer pT3 TNM Finding v8
}

National Cancer Institute

\section{Source}

National Cancer Institute. Prostatic Urethra CancerpT3 TNM Finding v8. NCI Thesaurus.

Code C140450.

Urethral cancer with tumor invading the periprostatic fat. (from AJCC 8th Ed.) 